University of Nebraska - Lincoln

DigitalCommons@University of Nebraska - Lincoln

Nomenclatural notes and identification of small-eared shrews (Mammalia: genus Cryptotis) from Cobán, Guatemala, in The Natural History Museum, London

Neal Woodman

USGS Patuxent Wildlife Research Center, woodmann@si.edu

Follow this and additional works at: https://digitalcommons.unl.edu/usgsstaffpub

Woodman, Neal, "Nomenclatural notes and identification of small-eared shrews (Mammalia: genus Cryptotis) from Cobán, Guatemala, in The Natural History Museum, London" (2011). USGS Staff -Published Research. 624.

https://digitalcommons.unl.edu/usgsstaffpub/624

This Article is brought to you for free and open access by the US Geological Survey at DigitalCommons@University of Nebraska - Lincoln. It has been accepted for inclusion in USGS Staff -- Published Research by an authorized administrator of DigitalCommons@University of Nebraska - Lincoln. 


\title{
Nomenclatural notes and identification of small-eared shrews (Mammalia: genus Cryptotis) from Cobán, Guatemala, in The Natural History Museum, London
}

\begin{abstract}
Neal Woodman
USGS Patuxent Wildlife Research Center, National Museum of Natural History, Smithsonian Institution, Washington, D.C. 20013-7012, U.S.A., e-mail: woodmann@si.edu

Abstract. - A small series of shrews collected in Guatemala and registered in the British Museum between 1843 and 1907 includes parts of type series for three species: Corsira tropicalis Gray (1843), Sorex micrurus Tomes (1862), and Blarina tropicalis Merriam (1895). These three names are now considered equivalent, but my recent review of the specimens comprising the series indicates that they include three distinct species: Cryptotis merriami Choate (1970), Cryptotis oreoryctes Woodman (2011), and Cryptotis tropicalis (Merriam 1895). I review the taxonomic history of these specimens, provide current identifications tied directly to museum register numbers, describe how to distinguish the three species, and provide revised synonymies for these species.
\end{abstract}

Keywords: Central America, shrew

As part of a long-term systematic study of small-eared shrews (Soricidae, Cryptotis) from Central and South America, I reviewed a series of historically important specimens, totaling twelve register numbers (i.e., catalog numbers), in The Natural History Museum, London [formerly the British Museum (Natural History)]. These were collected in the mid- to late-nineteenth century in what is now Alta Verapaz Department, Guatemala, mostly in the vicinity of Cobán. As is true of many older specimens, the identifications attached to these individuals have been revised through time. Subsets of these specimens have been interpreted as parts of type series for three separate species and were used to characterize these species by subsequent researchers: Corsira tropicalis Gray (1843), a nomen nudum; Sorex micrurus Tomes (1862), a secondary homonym rejected prior to 1960; and Blarina tropicalis Merriam (1895), now recognized as a species of Cryptotis. In the last comprehensive work to review this series of specimens, Choate (1970) mentioned only seven individuals, all of which he referred to the single subspecies, Cryptotis parva tropicalis. Unfortunately, he did not provide specific register numbers, making it impossible to be certain which $\mathrm{BMNH}$ specimens were examined. My study of the twelve specimens indicates that there are three species of small-eared shrews present, and these identifications are relevant to the taxonomic history of the three species names. My purposes here are to provide current identifications for each of the specimens and to elucidate characters that will help future researchers to identify these and other specimens from the region.

Nomenclatural Significance of Shrews from Cobán

The complex and intertwined nomenclatural histories of Corsira tropicalis, Sorex micrurus, and Blarina tropicalis, 
which I briefly summarize here, received considerable attention from Choate (1970) and Handley \& Choate (1970), and those papers may be consulted for more complete illumination of the topic.

The name Corsira tropicalis was first published in the 1843 Proceedings of the Zoological Society of London in a short notice announcing an exhibition of specimens of eight species of mammals from Cobán, Guatemala, six of which were judged to be "new to science" (Gray 1843:79). Included in the announcement is a list of scientific names of the specimens to be displayed, among which is the shrew Corsira tropicalis. Although one of the "new" species in this list was subsequently described by Gray (i.e., Heteromys desmarestianus Gray 1868; see Alston 1877, for the complete list), the other five were not, and Corsira tropicalis remains a nomen nudum. Gray's failure to follow up with a description of this species is somewhat surprising because it, along with a second species on the list, Corsira temlyas ( $=$ Sorex veraepacis Alston 1877), would have been the first species of American soricids known from south of the United States. There are seven specimens of small-eared shrews, genus Cryptotis, collected from near Cobán that, based on their BMNH register numbers (which begin with "43"), were catalogued into the collection in 1843 and would have been available to Gray at that time. At some point in time, a number of these specimens (e.g., BMNH 43.9.15.3, 43.9.15.4, 43.10.28.6, 43.10.28.7) were identified as Corsira tropicalis in the official register books. On the label of one of the seven specimens (BMNH 43.9.15.4), someone (possibly Oldfield Thomas) later wrote "type of Corsira tropicalis" and "Corsira tropicalis Gray. P. Z. S. 1843 p. 79 sine descr.," a clear reference to Gray's original publication of the name (Gray 1843). This specimen would be an unfortunate choice as a type, however, because it is comprised of parts from two individuals representing two different species, albeit species that were not recognized until relatively recently. The skin and dentaries are identifiable as Cryptotis merriami Choate (1970), whereas the large cranium, which has teeth with distinctly greater wear than the teeth of the dentaries, is from Cryptotis oreoryctes Woodman (2011). Among the other six register numbers in the 1843 series are three currently recognized species (Table 1).

Because Corsira tropicalis Gray remains a nomen nudum, the choice of a type specimen is not critical taxonomically. The history of the name and the specimen(s) on which the name is based are important, however, for comprehending later attempts to understand, describe, and name the entity that Gray informally recognized. Fortunately, Gray provided an indication of what he considered typical for the species by annotating a copy of his Catalogue of the Bones of Mammalia in the Collection of the British Museum (Gray 1862:115) with the number " 236 " next to the entry in that book for Corsira tropicalis (Paula D. Jenkins, in litt. 2 August 2011). This number corresponds to an unpublished catalog (GERM: J. E. Gray's Early Register of Mammalia, Natural History Museum, London) instituted by Gray in an early attempt at cataloging the collection. Specimen number 236, identified in the catalog as "Corsira Tropicalis," is specifically equated with "43.10.28.6 Skull a. Coban [sic], S. America" and paired with "43.9.15.3 Stuffed specimen in collection." This individual is the only specimen directly associated with the name Corsira tropicalis by Gray, and I agree with Paula Jenkins (in litt. 2 August 2011) that it should be considered the type for the species. Because BMNH 43.10.28.6 and the associated BMNH 43.9.15.3 represent a specimen of Cryptotis merriami (Table 1), the name Corsira tropicalis is a synonym of that species, rather than a synonym of Cryptotis tropicalis, as it has 
Table 1.- Identifications of specimens of Cryptotis from Alta Verapaz, Guatemala, in The Natural History Museum, London (BMNH). Numbers are $\mathrm{BMNH}$ register numbers and are listed in chronological order by registration date. Sample sizes are the numbers of individuals represented.

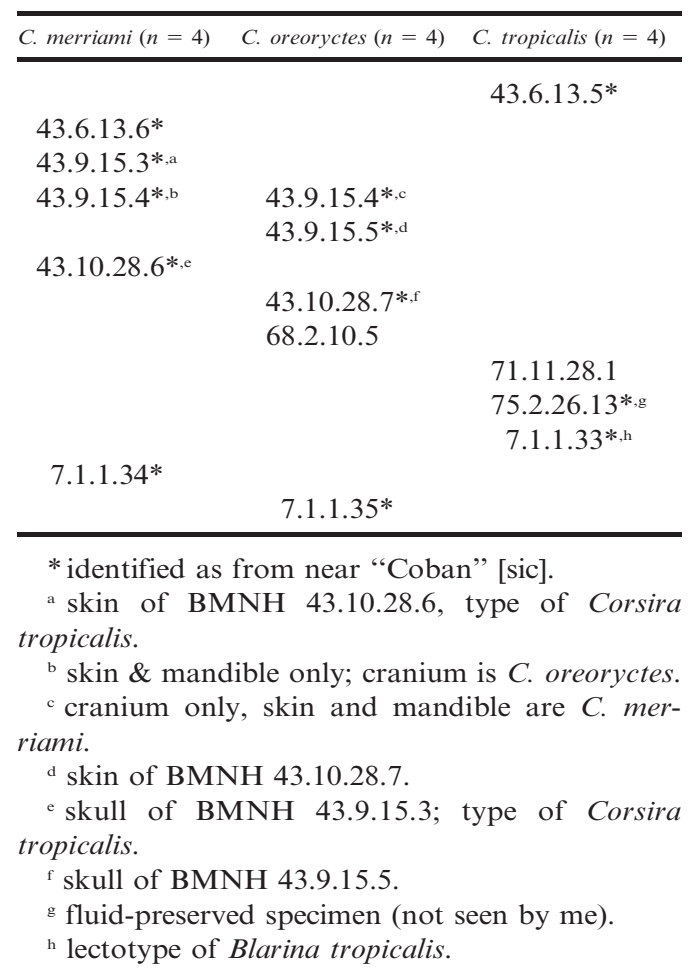

been treated previously (e.g., Choate 1970, Hutterer 2005).

Robert F. Tomes (1862:279) described Sorex micrurus based on two specimens "preserved in spirits" and "one preserved in skin" that he thought were from Dueñas, Guatemala. These specimens were obtained by Osbert Salvin during one of his first two trips to Central America (1857-1858, 1859-1860; Godman 1915). Edward R. Alston (1877; see also Coues 1877) subsequently determined that Sorex micrurus was the same taxon as Gray's Corsira tropicalis, and he corrected the type locality of $S$. micrurus to "near Coban" [sic] (Alston 18791882:56). Alston also reassigned the species to the genus Blarina (Alston 1877:446), where the name then be- came a secondary homonym of Galemys micrurus Pomel (1848), itself a subjective synonym of Sorex talpoides Gapper $(1830 ;=$ Blarina brevicauda talpoides; see Handley \& Choate 1970). Alston made his determination, however, without seeing Tomes' type specimens. After Elliott Coues sent him some North American shrews to compare with types in the British Museum, Alston replied, "I have not access to Mr. Tomes's types, but I have examined another of Mr. Salvin's specimens, in spirits ..." (Coues 1877: 638). His statement to Coues indicates that the types of $S$. micrurus were not in the museum's collection, nor were they probably in the private collection that Frederick D. Godman and Osbert Salvin then housed at Hanover Square, Westminster, for their work on the multivolume Biologia Centrali-Americana (Godman 1915). This is in contrast to Alston's (1879-1882:56) account for Blarina micrura in that series, where he appears to indicate that the specimens Tomes used to describe the species were from Salvin's collection. Yet, as Alston was chosen to complete the section on mammals for the project (Alston 18791882), he certainly would have had access to all of the specimens of mammals in Godman's and Salvin's collections as well as those in the British Museum. Most likely, the types of $B$. micrura were retained in Tomes' private collection until it was purchased by the British Museum after Tomes' death in 1904 (British Museum 1906:59).

Although C. Hart Merriam never saw Tomes' types either, he subsequently designated the two fluid-preserved specimens Tomes used to describe Sorex micrurus as "the two original type specimens" when he provided the name Blarina tropicalis to replace Sorex micrurus (Merriam 1895:21-22). Merriam's concept of $S$. micrurus likely was influenced by the illustration of the species in the Mammalia volume of Biologia Cen- 


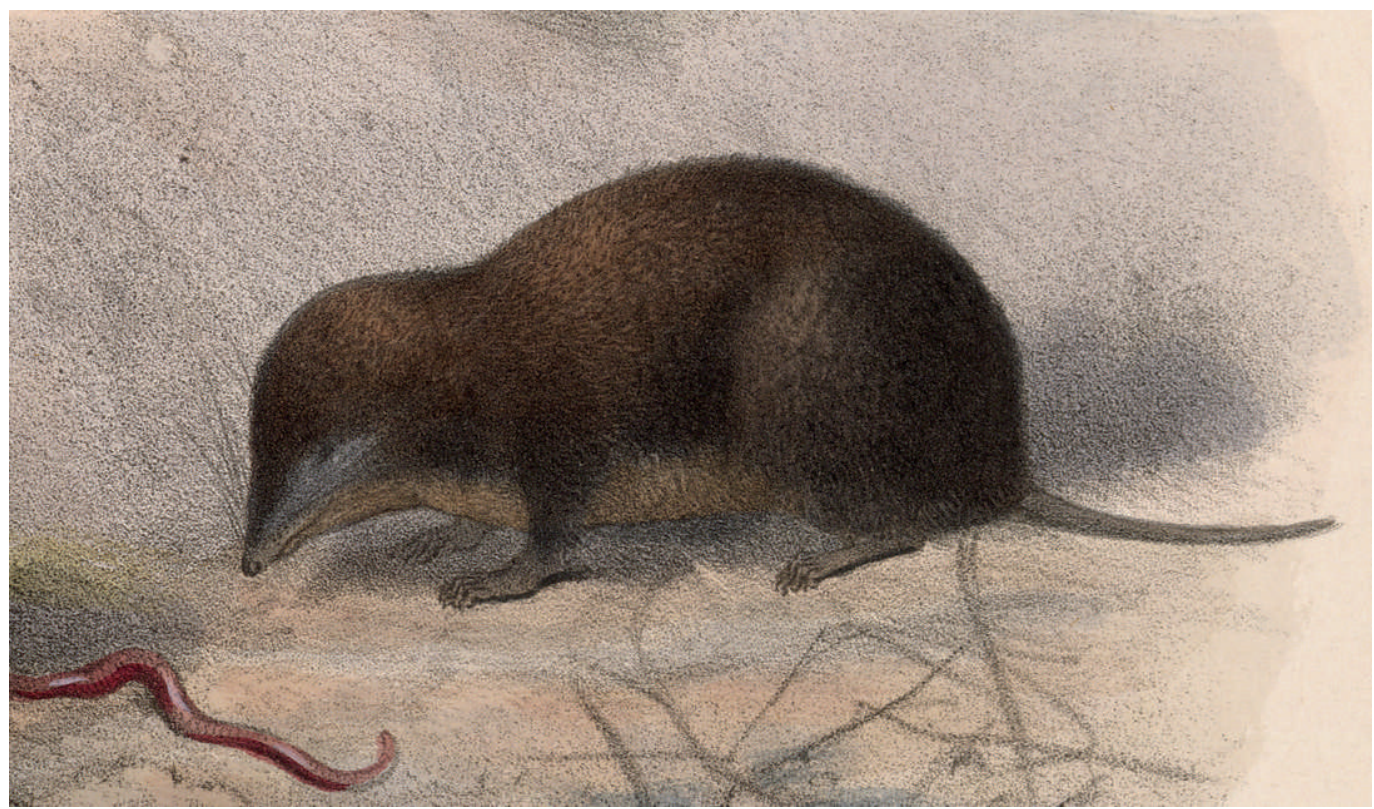

Fig. 1. Blarina micrura (Tomes, 1862) contemplating a small earthworm. Note the distinctly paler ventral pelage, relatively short tail, and short foreclaws. Detail from Table 5 of Alston's (1879-1882) volume on the Mammalia in Biologia Centrali-Americana (Smithsonian Institution Libraries, Joseph F. Cullman III, Library of Natural History, Washington, D.C.).

trali-Americana (Alston 1879-1882: Table 5). This illustration clearly shows the distinctly paler ventral pelage, short tail, and short fore claws that today help to distinguish Cryptotis tropicalis (Merriam) from other small-eared shrews in the region (Fig. 1).

Choate (1970:269) formally designated a lectotype for Merriam's (1895) Blarina tropicalis, selecting a dried skin and skull (BMNH 7.1.1.33) based in part on the strength of a written note from $\mathrm{R}$. W. Hayman that stated, "[Oldfield] Thomas marked this number in the margin of our PZS [Proceedings of the Zoological Society of London] in Tomes' description, and labelled the specimen co-type and lectotype" (Handley \& Choate 1970:196; Choate 1970). The label on the specimen gives the year of collection as 1859, which was during Salvin's second trip to Guatemala (Godman 1915). The BMNH register number indicates the dried skin was not registered until 1907. In contrast, there is no record of the two fluid-preserved specimens from the type series of $S$ micrurus having been accessioned into the BMNH then, or at any other time (R. Portela Miguez, in litt. 6 January 2011). The fate of those two specimens is unknown, and it is likely that they no longer exist. In making his selection of a lectotype, Choate chose a specimen that was likely part of the type series for $S$. micrurus, but one that was not even mentioned by Merriam (1895) in his description of Blarina tropicalis. Despite this latter fact, Choate's decision was the most appropriate move for stabilizing the name and for preserving the identity of the species as conceived by Tomes, Alston, and Merriam.

\section{Identities of Small-Eared Shrews from Alta Verapaz}

My study of twelve register numbers of dried skins and/or skulls of small-eared shrews from Alta Verapaz in the BMNH revealed three currently recognized species 
(Table 1). In addition, a fluid-preserved specimen of Cryptotis collected near Cobán (BMNH 75.2.26.13) was discovered in the BMNH collection in January 2011 (Roberto Portela Miguez, in litt. 11 January 2011). This is most likely the specimen of $S$. micrurus that Alston consulted and to which he referred in his letter to Coues (1877).

Cryptotis tropicalis (3 individuals).Specimens of $C$. tropicalis include a skin and skull from "Coban" [sic] (BMNH 43.6.13.5); a skull without skin [although the label reads, "skin in collection," indicating a skin once existed] from "Guatemala" (BMNH 71.11.28.1) that was purchased from Mr. Henry Whitely; and the skin and skull of the lectotype of Blarina tropicalis (BMNH 7.1.1.33), whose label reads "Duenas [sic], Guatemala."

Cryptotis merriami (4 individuals). - The five register numbers (BMNH 43.6.13.6, 43.9.15.3, 43.9.15.4, 43.10.28.6, 7.1.1.34) consist of skins and skulls from "Coban" [sic]. BMNH 43.10.28.6 is a skull associated with skin BMNH 43.9.15.3. Because this is the only specimen definitively associated with the name Corsira tropicalis by Gray, it should be considered the type for that species. The skin label attached to another specimen (BMNH 43.9.15.4) bears the hand-written notation, "type of Corsira tropicalis." This is a mixed specimen, however, as the skin and dentaries are identifiable as C. merriami, but the larger cranium as $C$. oreoryctes. The maxillary teeth also exhibit distinctly greater wear than the mandibular teeth, indicating two individuals of differing ages. The skull of BMNH 7.1.1.34 was unprepared until 2002, when I borrowed this specimen to clean and identify it.

Cryptotis oreoryctes (4 individuals).In addition to the cranium of $\mathrm{BMNH}$ 43.9.15.4, there are four register numbers of $C$. oreoryctes, but representing only three individuals, each comprised of a dried skin and a skull. BMNH 7.1.1.35
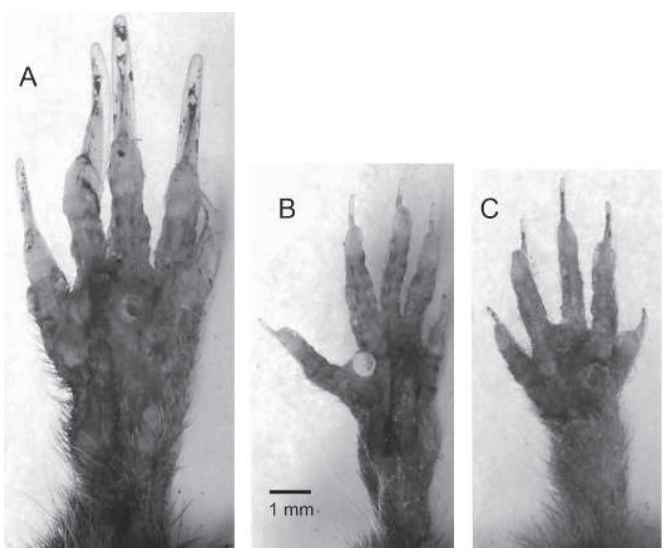

Fig. 2. Ventral (palmar) view of the right fore feet from dried skins of: A, Cryptotis oreoryctes (USNM 569877); B, C. merriami (USNM 570112); C, C. tropicalis (USNM 570435).

and BMNH 43.9.15.5 (a previously mounted skin with glass eyes associated with skull BMNH 43.10.28.7) are both from "Coban" [sic]. BMNH 68.2.10.5 is a young individual with lightly worn dentition, whose label states that it is from "Verapaz" and was "purchased of O. Salvin." Salvin probably obtained this specimen during either his second (1859$1860)$ or third trip (1861-1863) to Guatemala, when he spent time at "Coban and other places in Vera Paz" [sic] (Godman 1915:3).

\section{Characters of Small-Eared Shrews from} Alta Verapaz

The three species of small-eared shrews from Alta Verapaz, Guatemala, are most easily distinguished by a combination of characters, including relative body size, size of fore feet, length of fore claws, and skull size and proportions. These three species are not typically found together, indicating that the collectors had access to a variety of habitats at a range of elevations in Alta Verapaz. Additional information on the identification of these and other species of small-eared shrews in Guatemala is available in Woodman (2010, 2011). 
Table 2.- Selected measurements (in mm) from three species of Cryptotis that occur near Cobán, Guatemala. Statistics are mean $\pm S D$ and range. Specimens on which these measurements are based are listed in Appendix 1.

\begin{tabular}{|c|c|c|c|}
\hline Variable & C. tropicalis & C. merriami & C. oreoryctes \\
\hline Head and body length (HB) & $\begin{array}{l}68 \pm 7 \\
53-78 \\
(n=17)\end{array}$ & $\begin{array}{c}69 \pm 4 \\
60-77 \\
(n=30)\end{array}$ & $\begin{array}{c}82 \pm 5 \\
77-86 \\
(n=3)\end{array}$ \\
\hline Tail length (TL) & $\begin{array}{c}23 \pm 3 \\
18-29 \\
(n=17)\end{array}$ & $\begin{array}{c}29 \pm 3 \\
22-34 \\
(n=30)\end{array}$ & $\begin{array}{c}30 \pm 2 \\
28-32 \\
(n=3)\end{array}$ \\
\hline$\%$ Tail length $(\mathrm{HB} / \mathrm{TL} \times 100)$ & $\begin{array}{c}34 \pm 4 \\
25-41 \\
(n=17)\end{array}$ & $\begin{array}{c}42 \pm 5 \\
32-50 \\
(n=30)\end{array}$ & $\begin{array}{c}36 \pm 3 \\
33-39 \\
(n=3)\end{array}$ \\
\hline Length of hind foot (including claw) & $\begin{array}{c}12 \pm 1 \\
11-13 \\
(n=5)\end{array}$ & $\begin{array}{c}12 \pm 0.5 \\
11-12 \\
(n=6)\end{array}$ & $\begin{array}{c}15 \\
(n=3)\end{array}$ \\
\hline Condylobasal length & $\begin{array}{r}17.8 \pm 0.6 \\
17.0-18.6 \\
(n=12)\end{array}$ & $\begin{array}{r}19.5 \pm 0.4 \\
18.7-20.2 \\
\quad(n=22)\end{array}$ & $\begin{array}{c}21.4 \pm 0.2 \\
21.1-21.5 \\
(n=3)\end{array}$ \\
\hline Breadth of braincase & $\begin{array}{l}8.8 \pm 0.3 \\
8.3-9.3 \\
(n=12)\end{array}$ & $\begin{array}{r}9.5 \pm 0.2 \\
9.2-10.0 \\
(n=23)\end{array}$ & $\begin{array}{c}10.9 \pm 0.4 \\
10.5-11.3 \\
(n=3)\end{array}$ \\
\hline Length of palate & $\begin{array}{l}7.5 \pm 0.3 \\
7.1-8.1 \\
(n=22)\end{array}$ & $\begin{array}{c}8.5 \pm 0.3 \\
7.9-9.3 \\
(n=34)\end{array}$ & $\begin{array}{c}9.4 \pm 0.4 \\
9.0-10.1 \\
(n=7)\end{array}$ \\
\hline Breadth across upper second molars & $\begin{array}{l}5.4 \pm 0.2 \\
5.1-5.9 \\
(n=22)\end{array}$ & $\begin{array}{c}5.8 \pm 0.2 \\
5.2-6.3 \\
(n=34)\end{array}$ & $\begin{array}{c}6.2 \pm 0.2 \\
5.9-6.4 \\
(n=5)\end{array}$ \\
\hline Length of maxillary toothrow $\left(\mathrm{U}^{1}-\mathrm{M}^{3}\right)$ & $\begin{array}{l}6.6 \pm 0.2 \\
6.3-7.3 \\
(n=20)\end{array}$ & $\begin{array}{l}7.4 \pm 0.3 \\
6.8-8.0 \\
(n=32)\end{array}$ & $\begin{array}{c}8.3 \pm 0.2 \\
8.1-8.5 \\
(n=5)\end{array}$ \\
\hline Length of upper molariform toothrow $\left(\mathrm{P}^{4}-\mathrm{M}^{3}\right)$ & $\begin{array}{l}4.7 \pm 0.2 \\
4.5-5.2 \\
(n=22)\end{array}$ & $\begin{array}{c}5.3 \pm 0.2 \\
5.0-5.7 \\
(n=29)\end{array}$ & $\begin{array}{c}5.8 \pm 0.2 \\
5.5-6.0 \\
(n=6)\end{array}$ \\
\hline Length of mandible & $\begin{array}{l}5.7 \pm 0.2 \\
5.3-6.1 \\
(n=21)\end{array}$ & $\begin{array}{l}6.5 \pm 0.3 \\
5.8-7.2 \\
(n=36)\end{array}$ & $\begin{array}{c}6.8 \pm 0.1 \\
6.7-6.9 \\
(n=5)\end{array}$ \\
\hline Height of coronoid process & $\begin{array}{l}4.4 \pm 0.2 \\
4.1-4.7 \\
(n=21)\end{array}$ & $\begin{array}{l}5.0 \pm 0.2 \\
4.5-5.3 \\
(n=36)\end{array}$ & $\begin{array}{c}4.7 \pm 0.1 \\
4.6-4.9 \\
(n=5)\end{array}$ \\
\hline
\end{tabular}

Cryptotis oreoryctes is substantially larger than $C$. merriami and $C$. tropicalis, and $C$. merriami has a proportionally longer tail than $C$. tropicalis (Table 2), so external measurements recorded from fresh specimens are helpful for distinguishing these species. Cryptotis tropicalis has paler dorsal pelage than $C$. oreoryctes and $C$. merriami, and its ventral pelage is even paler, contrasting noticeably with the dorsal pelage, unlike in the other two species. Unfortunately, these characters may be of limited usefulness for identify- ing older dried skins because older specimens often lack recorded field measurements, body proportions can be considerably distorted during preparation of the skin, and pelage color typically is faded. Despite these problems, $C$. oreor$y$ ctes can be distinguished easily from $C$. merriami and $C$. tropicalis by its substantially larger fore feet, particularly its longer and broader foreclaws (Fig. 2A-C).

The skulls of the three species are substantially easier to identify, because they represent distinct size classes that can 
be distinguished by a number of common measurements (Table 2).

Cryptotis oreoryctes.-Specimens of this recently-described species (Woodman 2011) previously would have been identified as the closely related species, Cryptotis goodwini Jackson (1933). Cryptotis oreoryctes has the largest skull of the three species from Cobán, and it can be distinguished from $C$. merriami and $C$. tropicalis by nearly any variable, except breadth across the upper second molars and height of coronoid process (Table 2). These two variables reflect its relatively narrow palate and its distinctively low, narrow coronoid process, the anterior border of which joins the horizontal ramus of the mandible at a relatively low angle. In addition, $C$. oreoryctes has a moderately broad zygomatic plate whose posterior border is confluent with the posterior border of the maxillary process and posterior to the posterior edge of the palate; slightly concave posterior margins of upper fourth premolar and first and second molars; relatively high, narrow articular process; deep lower sigmoid notch, which extends ventral to the lower branch of articular process; long, low cusp of lower third premolar; and a vestigial entoconid is sometimes present on the talonid of the lower third molar.

Cryptotis merriami.-Intermediate in size for most measurements, C. merriami has a relatively broad palate, as reflected by breadth across upper second molars (Table 2). It has a very broad zygomatic plate whose posterior border is approximately even with the posterior border of the maxillary process, but anterior to the posterior edge of the palate; nearly straight posterior margins of upper fourth premolar and first and second molars; high, broad coronoid process, the anterior border of which forms a nearly right angle with the horizontal ramus; relatively high, narrow articular process; relatively low, broad articular process; no lower sigmoid notch; short, high cusp of lower third premolar; no entoconid on lower third molar.

Cryptotis tropicalis.-The smallest of the three species, $C$. tropicalis has a relatively broad palate; a narrow zygomatic plate, the posterior border of which is anterior to the posterior border of the maxillary process and well anterior to the posterior edge of the palate; noticeably concave posterior margins of upper fourth premolar and first and second molars; high, narrow coronoid process, the anterior border of which forms a near right angle with the horizontal ramus; relatively low, broad articular process; shallow lower sigmoid notch; short, high cusp of lower third premolar; no entoconid on lower third molar.

\section{Summary and Synonymy}

Taxonomically important nineteenthcentury specimens of small-eared shrews in the BMNH from Alta Verapaz, Guatemala, include three valid species. Study of the specimens and records indicates that the type specimen for Corsira tropicalis Gray (1843) is BMNH 43.10.28.6 (skull) and corresponding BMNH 43.9. 15.3 (skin). This specimen is identifiable as Cryptotis merriami Choate (1970), indicating that Corsira tropicalis is a synonym of that species rather than Cryptotis tropicalis (Merriam 1895), as had long been assumed.

Two of the three specimens that served as the type specimens for Sorex micrurus Tomes (1862) also served as the types for Blarina tropicalis Merriam (1895). These were fluid-preserved shrews that never entered the collection of the BMNH and probably no longer exist. The third specimen is a dried skin and skull that is registered as $\mathrm{BMNH}$ 7.1.1.33. It was designated by Choate (1970) as the lectotype for Blarina tropicalis.

A modified synonymy for the three species included in this group of shrews follows. 
Cryptotis merriami Choate, 1970

Cryptotis nigrescens merriami Choate (1970:277). Type locality "Jacaltenango, 5400 ft., Huehuetenango, Guatemala."

Corsira tropicalis Gray (1843:79). Nomen nudum.

Cryptotis nigrescens, Goodwin (1942: 117). Not Cryptotis nigrescens (J. A. Allen 1895) [part].

Cryptotis parva orophila, Choate (1970: 264). Not Cryptotis orophila (J. A. Allen 1895) [part_one specimen from Santa María de Ostuma, Nicaragua].

Cryptotis nigrescens nigrescens, Choate (1970:281). Not Cryptotis nigrescens (J. A. Allen 1895) [part-one specimen from $4.5 \mathrm{~km}$ NE Tilarán, Costa Rica].

Cryptotis merriami, Woodman \& Timm (1993:14). Name combination.

Cryptotis oreoryctes Woodman, 2011

Cryptotis oreoryctes Woodman (2011: 1280). Type locality "Chelemhá Cloud Forest Reserve (ca. $15^{\circ} 23^{\prime} \mathrm{N}, 90^{\circ} 04^{\prime} \mathrm{W}$ ), ca. 2090 mamsl, Alta Verapaz, Guatemala."

\section{Cryptotis tropicalis (Merriam 1895)}

Blarina tropicalis Merriam (1895:21). Replacement name for Sorex micrurus Tomes (1862).

Sorex micrurus Tomes (1862:279). Type locality "Dueñas, Guatemala" [corrected to "Guatemala, Coban" by Alston (1879-1882)].

Blarina micrura, Alston (1877:445). Name combination.

C[ryptotis]. tropicalis, Miller (1911:221). Name combination.

Cryptotis micrura, Miller (1924:32). Name combination.

Cryptotis tropicalis, Handley \& Choate (1970:200). Name combination.

Cryptotis parva tropicalis, Choate (1970:269). Name combination [lectotype designated].
Acknowledgments

Thanks to L. Overstreet, E. C. Rushing, and D. Wingreen-Mason for the image from the Smithsonian Libraries' copy of Biologia Centrali-Americana and for granting permission to reprint it here. My deep gratitude to P. D. Jenkins and R. Portela Miguez of BMNH for searching the official registers and correspondence files and providing valuable information regarding their shrews from Alta Verapaz. I appreciate the assistance of the following curators and collection managers for loans or for permission to examine specimens under their care: N. B. Simmons, R. S. Voss, and E. Westwig $(\mathrm{AMNH}) ;$ P. D. Jenkins, R. Portela Miguez, and L. Tomsett (BMNH); S. T. Alvarez (ENCB); J. M. Chupasko (MCZ); J. R. Choate (MHP); G. Pothet, M. Tranier, and C. Denys (MNHN); J. L. Patton and E. Lacey (MVZ); F. Spitzenberger (NMW); G. Storch (SMF); P. Myers (UMMZ); G. A. Cruz (UNAH); F. Cervantes R. (UNAM). S. Feinstein, A. L. Gardner, P. D. Jenkins, R. P. Reynolds, and R. M. Timm provided valuable comments on previous versions of this manuscript. Any use of trade, product, or firm names is for descriptive purposes only and does not imply endorsement by the U.S. government.

\section{Literature Cited}

Allen, J. A. 1895. Descriptions of new American mammals.-Bulletin of the American Museum of Natural History 7:327-340.

Alston, E. R. 1877. On an undescribed shrew from Central America.-Proceedings of the Zoological Society of London 1877:445-446. . 1879-1882. Biologia centrali-americana. Mammalia. R. H. Porter, London, [Parts 2 and 3, which cover Blarina micrura, were published November 1879 and February 1880, respectively.]

British Museum (Natural History), The history of the collections contained in the Natural History Departments of the British Museum. vol. II. Separate historical accounts of the 
several collections included in the Department of Zoology. William Clowes \& Sons, Limited, London.

Choate, J. R. 1970. Systematics and zoogeography of Middle American shrews of the genus Cryptotis.-University of Kansas Publications, Museum of Natural History 19(3):195-317.

Coues, E. 1877. Precursory notes on American insectivorous mammals, with descriptions of new species.-Bulletin of the United States Geological and Geographical Survey of the Territories 3:631-653.

Gapper, Dr. 1830. Observations on the quadrupeds found in the district of upper Canada extending between York and Lake Simcoe, with the view of illustrating their geographical distribution, as well as of describing some species hitherto unnoticed.-The Zoological Journal 5:201-207.

Godman, F. D. 1915. Biologia centrali-americana. Zoology, botany, and archæology. Introductory volume. R. H. Porter, London.

Goodwin, G. G. 1942. Mammals of Honduras.Bulletin of the American Museum of Natural History 79:107-195.

Gray, J. E. 1843. Exhibition of specimens of Mammalia from Coban in Central America.-Proceedings of the Zoological Society of London Part 11(1843):79.

1862. Catalogue of the bones of Mammalia in the collection of the British Museum. British Museum (Natural History), London. 1868. Synopsis of the species of Saccomyinae, or pouched mice, in the collection of the British Museum.-Proceedings of the Zoological Society of London 1868:199-206.

Handley, C. O. Jr, \& J. R. Choate. 1970. The correct name for the least short-tailed shrew (Cryptotis parva) of Guatemala (Mammalia: Insectivora).-Proceedings of the Biological Society of Washington 83:195-202.

Hutterer, R. 2005. Order Soricomorpha. Pp. 220-311, in D. E. Wilson and D. M. Reeder, eds., Mammal species of the world: a taxonomic and geographic reference. Third edition. The Johns Hopkins University Press, Baltimore.

Jackson, H. H. T. 1933. Five new shrews of the genus Cryptotis from Mexico and Guatemala.-Proceedings of the Biological Society of Washington 46:79-81.

Merriam, C. H. 1895. Revision of the shrews of the American genera Blarina and Notiosorex.North American Fauna 10:5-34.

Miller, G. S. Jr 1911. Three new shrews of the genus Cryptotis.-Proceedings of the Biological Society of Washington 24:221-223.
1924. List of North American recent mammals, 1923.-Bulletin of the United States National Museum 128:1-673.

Pomel, A. 1848. Etudes sur les carnassiers insectivores (Extrait). Seconde partie.-Classification des insectivores.-Archives des Sciences Physiques et Naturelles, Genève 9:244-251.

Tomes, R. F. 1862. Report of a collection of mammals made by Osbert Salvin, Esq., F. Z. S., at Dueñas, Guatemala; with notes on some of the species, by Mr. Fraser.-Proceedings of the Zoological Society of London 1861:278-288.

Woodman, N. 2010. Two new species of shrews (Soricidae) from the western highlands of Guatemala.-Journal of Mammalogy 91(3): 566-579.

- 2011. Patterns of morphological variation among semi-fossorial shrews in the highlands of Guatemala, with the description of a new species of small-eared shrew (Mammalia, Soricomorpha, Soricidae).-Zoological Journal of the Linnean Society 163:1267-1288.

, \& R. M. Timm. 1993. Intraspecific and interspecific variation in the Cryptotis nigrescens species complex of small-eared shrews (Insectivora: Soricidae), with the description of a new species from Colombia._Fieldiana: Zoology, new series 74:1-30.

Associate Editor: Michael D. Carleton.

Appendix 1

Specimens Measured for Table 2

Specimens from the following institutions were used in this study: American Museum of Natural History, New York (AMNH); The Natural History Museum, London (BMNH); Escuela Nacional de Ciencias Biológicas, Mexico City (ENCB); Museum of Comparative Zoology, Cambridge (MCZ); Museum of the High Plains, Fort Hays State University, Hays, Kansas (MHP); Muséum National d'Histoire Naturelle, Paris (MNHN); Museum of Vertebrate Zoology, University of California, Berkeley (MVZ); Naturhistorisches Museum Wien, Vienna (NMW); Senckenberg Forschungsinstitut und Naturmuseum, Frankfurt am Main (SMF); University of Michigan Museum of Zoology, Ann Arbor (UMMZ); Universidad Nacional Autónoma de Honduras, Tegucigalpa (UNAH); Instituto de Biología, Universidad Nacional Autónoma de México, Mexico City (UNAM); National Museum of Natural History, Washington, D.C. (USNM).

Cryptotis merriami (39).-EL SALVADOR: Morazan: Mt. Cacaguatique, north slope, 3800-4000 ft 
(MVZ 98176-98178). San Miguel: Mt. Cacaguatique, 3500-4000 ft (MVZ 130328-130335; UMMZ 109892, 109893). GUATEMALA: no locality (MNHN 19622895). Alta Verapaz: Cobán (BMNH 43.6.13.6, 43.9.15.3/43.10.28.6, 43.9.15.4 [skin \& mandibles only], 7.1.1.34); San Pedro Carchá (ENCB 35699); Hacienda Concepción, 1100-1320 m (UMMZ 117845; USNM 570108, 570112); Finca Xicacao (UMMZ 87869). Baja Verapaz: Hotel Country Delights, 1640-1665 m (USNM 570122, 570132). Huehuetenango: Hacienda Santa Gregoria, Barillas (UMMZ 117844); Jacaltenango, $5400 \mathrm{ft}$ (USNM 77020, 77048-77050 - holotype). Zacapa: El Limo, 1475 m (USNM 570049, 570125). HONDURAS: El Paraiso: Yuscarán, Cerro de Moncerrato, cloud forest (MCZ 42992). Francisco Morazán: La Rosario, San Juancito, La Tigra National Park (UNAH no number). Lempira: Las Flores Gracias (AMNH 129758). Santa Barbara: San José de las Colinas (AMNH 123567). MEXICO: Chiapas: Volcán
Kagchiná, 3.5 km N Las Margaritas, 1500 m (MHP *8779, 2 specimens). NICARAGUA: Matagalpa: Santa María de Ostuma, $9 \mathrm{mi} \mathrm{N}$ of Matagalpa, 1400 m (UMMZ 117111).

Cryptotis oreoryctes (7). - GUATEMALA: Alta Verapaz: Chelemhá, 2090 m (USNM 569854, 569877, 569878); Cobán (BMNH 43.9.15.4 [cranium only]; 43.9.15.5/43.10.28.7, 7.1.1.35); "Verapaz" (BMNH 68.2.10.5).

Cryptotis tropicalis (22).-BELIZE: Mountain Pine Ridge, 12 mi S Cayo (UMMZ 63008-63011). GUATEMALA: no locality (BMNH 71.11.28.1; NMW 12090). Alta Verapaz: Cobán (BMNH 43.6.13.5, 7.1.1.33). Huehuetenango: La Trinidad (USNM 570435). Sololá: Panajachel, $4900 \mathrm{ft}$ (AMNH 74295-74301). MEXICO: "Mexico" (MNHN 1869152). Chiapas: no locality (ENCB 76); Liquidambar (SMF 11477a); Finca Prusia, 1110 m (UNAM 18, 170); Barranca de Río Malá, Volcán Tacaná (UNAM 9063). 